Eos, Vol. 80, No. 32, August 10, 1999
E O S ,
TR A N SACTIONS,
A M E R I C A N
GE O PH Y S C A L
U N I O N

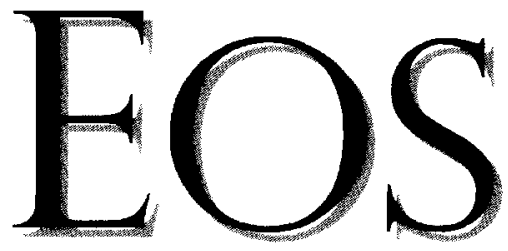

VOLUME 80 NUMBER 32

AUGUST 10, 1999

PAGES 353-364

\title{
Little-studied Arc-Backarc System in the Spotlight
}

\section{PAGES 353, 359}

A research cruise has documented changes in rift tectonics, volcanism, and hydrothermalism along the least studied and most enigmatic sector of a crustal complex in the southwest Pacific Ocean. Results from the longitudinal transect are expected to provide insight into processes involving the Kermadec arcHavre backarc (KAHB) system, a continuum from oceanic spreading to continental rifting at a convergent plate boundary. KAHB forms the central sector of an active, $2000-\mathrm{km}$ arcbackarc complex between Tonga and New Zealand (Figure 1).

The expedition also engaged in the first comprehensive survey of submarine vents in the Taupo Volcanic Zone (TVZ) at the south end of the KAHB system. Identified in the offshore segment of TVZ were three major hydrothermal vent areas associated with late Quaternary fault structures. Data from the expedition and from other recent research in the same area addressed questions concerning the type of hydrothermal venting, magmatic heterogeneity along and across $\mathrm{KAHB}$, the style of backarc rifting, and tectonic and magmatic consequences of anomalous terranes colliding with the subduction margin

The cruise, aboard the R/V Sonne, took place in late 1998 and involved a consortium of five German universities, three New Zealand research groups, and other scientists. Known as SO-135 and lasting 37 days, the expedition had two legs (Figure 1), the first collecting seismic reflection data and undertaking rock dredging and seafloor imaging along the Kermadec arc and the central Havre trough, the second imaging and sampling at the TVZ hydrothermal vents.

KAHB forms an archetypal example of a backarc basin from which, in part, the backarc basin concept first originated [Karig, 1970]. To its north, the crustal complex has evolved into full oceanic spreading of the Lau Basin backarc with concomitant volcanism along the Tofua arc. To the south, the TVZ proceeds onto land, with volcanism and rifting within the continental crust of central North Island, New Zealand. The general structure is southward propagating rifting preceding southward propagating spreading, although collision of seamount chains, and possibly submarine plateaus, along the subduction margin overprints the system.

\section{Central Havre Trough}

The acquired data reveal the volcanic morphology (including in part the submarine flanks of Curtis and Macauley Island volcanoes) and backarc rifting fabric for the segment of the KAHB system between $30^{\circ}$ and $30^{\circ} 40^{\prime}$ south latitude. In the west, the remnant Colville arc ridge, cored volcanic basement, and overlying volcaniclastic sediment sequences are downthrown to the east by a series of listric normal faults along the ridge's eastern flank. The oldest volcaniclastic sequences are extensively faulted and record both the early phases of arc volcanism and rifting.

The backarc proper comprises western and eastern subbasins flanking a central volcanic basement block. The latter, with a well-defined rift fabric, has bimodal strike orientations of $21^{\circ}-31^{\circ}$ and $63^{\circ}$. The western subbasin, with a sedimentary sequence thickness of $0.4-0.8 \mathrm{~s}$ two-way time [TWT], overlying volcanic basement, records basin infilling from the west, with little evidence of postdepositional deformation. The eastern subbasin is the dominant site of present-day extensional faulting, comprising a pervasively faulted sedimentary sequence of variable thickness of $\leq 1$ s TWT. Faults predominantly dip west, with the larger having seafloor relief. In the south, the basin narrows to a $10-\mathrm{km}$-wide rift, flanked by basement horsts.

To the east, the Kermadec Ridge appears to comprise a basement core of the older protoColville-Kermadec arc and associated volcaniclastic sequences possibly 10-5 Myr, capped with volcanoes of the present-day arc front and attendant volcaniclastic sedimentation. It is hoped that multichannel seismic processing will better resolve the lowermost chaotic sequence of reflectors that in part may represent intercalated sequences of older volcaniclastic sediments and true acoustic basement. Border faults along the lower western flank of the arc generally strike $25^{\circ}$ and are interpreted as a series of west dipping, low-angle normal faults.

\section{Brothers Hydrothermal Site}

The Brothers caldera ( $34^{\circ} 52^{\prime}$ south latitude, $179^{\circ} 04^{\prime}$ east longitude) is one of three presently known southern Kermadec arc calderas and one of two known sites of hydrothermalism and associated sulfide mineralization within the KAHB system [Wright et al., 1998]. The caldera is $3-3.5 \mathrm{~km}$ wide, with the surrounding wall rising some $350-450 \mathrm{~m}$ to the rim at water depths of $1560-1320$ m. A resurgent dome coalesces in part with the inner southern caldera wall.

Before the expedition the presence of an active hydrothermal system within the caldera was hinted at by two sites of sulfide mineralization on the caldera wall and the recovery of two partial specimens of caridean shrimp from the resurgent dome. New data reveal the presence of an active, high-temperature "black smoker" hydrothermal vent field and associated extensive alteration and mineralization within the caldera. On the northern wall, active hydrothermal venting is associated with free-standing chimneys (1-5 $\mathrm{m}$ high) with abundant massive and talus sulfides (Figure 2a). Smaller fields with black smoker vents and inactive chimneys also occur higher on the wall, and a relict field is sited near the sediment-covered rim.

Recovered hydrothermal rocks included pyrite-anhydrite breccias, a single massive sphalerite chimney, massive pyrite crusts and breccias, pyritic stockwork material, and $\mathrm{Fe}$ oxide-silica crusts.Vent-specific macrofauna associated with hydrothermal fields included dead clam shells and stalked barnacles, white filamentous bacteria, living barnacles, galatheid crabs, and shrimps (Figure $2 \mathrm{~b}$ ).

A large near-bottom plume was associated with the resurgent dome, the latter con- 


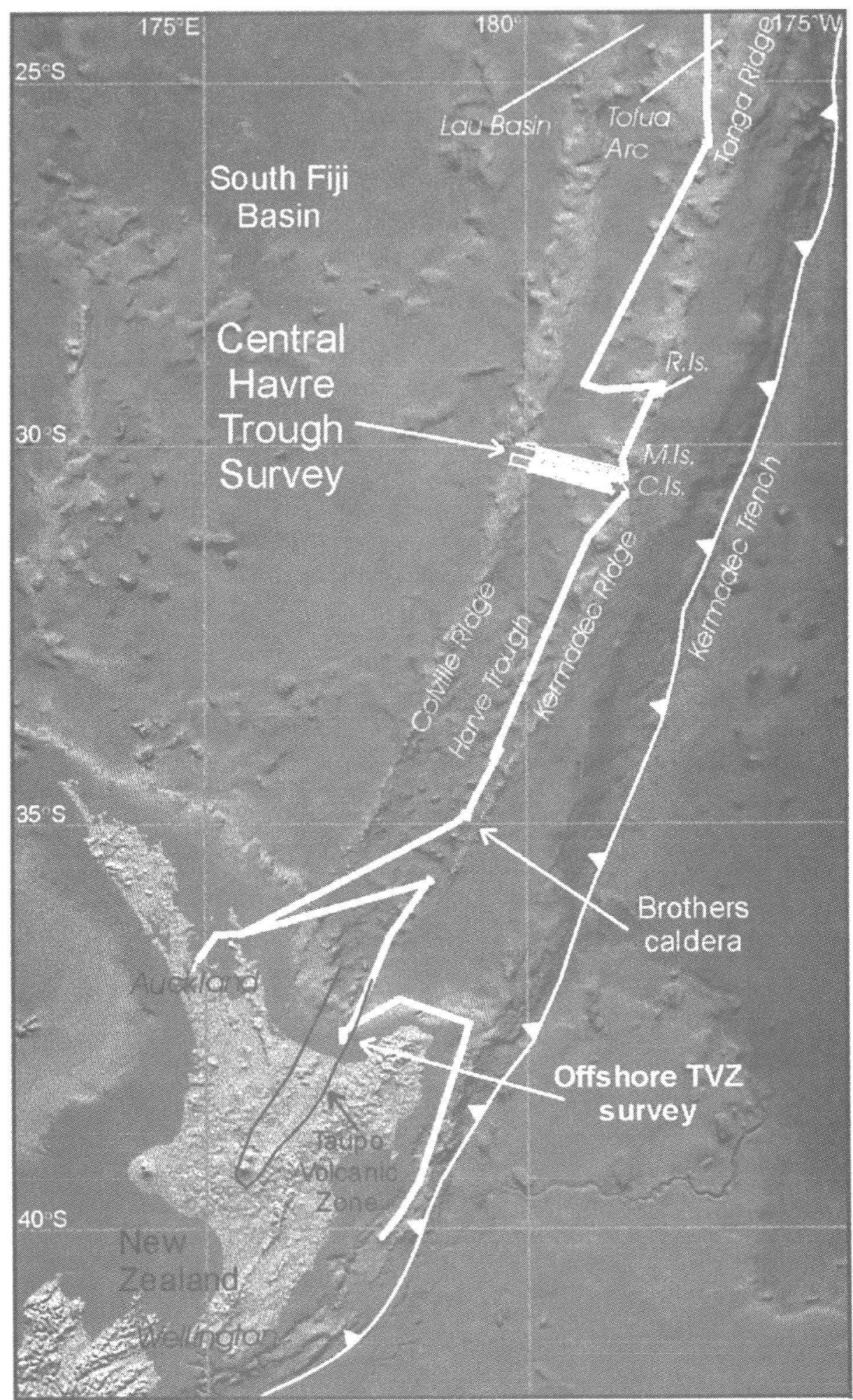

Depths in Metres

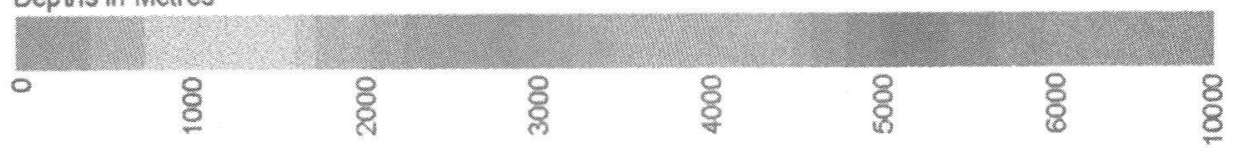

Fig. 1. Regional structure (southwest Pacific) and ship track of the R/V Sonne SO-135 cruise. R.Is., M.Is., and C.Is., are Raoul, Macauley, and Curtis Islands, respectively. Original color image appears at the back of this volume. sisting of extensive glassy dacite talus and an extensive zone of Fe-oxide staining and alteration and locally encrusting native sulfur.Vent-related fauna there included sulfide worms, limpets, white filamentous bacteria, shrimp, and several large fields of stalked barnacles.

\section{Offshore TVZ Site}

The offshore TVZ is a region of known submarine hydrothermal venting with observations of gas bubbling, metalliferous sediments, and anhydrite mounds (including Calypso vents) associated with active normal faults [Sarano et al., 1989; Pantin and Wright, 1994]. Multibeam mapping was done there, as well as seafloor video and photo imaging and rock sampling. Manned dives in the submersible JAGO undertook vent sampling and observation. (For more on JAGO, see the Web site http://www.mpi-seewiesen. mpg.de/ hissmann/jago.html.) These observations, with the acquired vent fluids and associated hydrothermally altered rock dredge samples, provide an excellent opportunity to characterize an active, gaseous, shallow-water, hydrothermal system. The late Quaternary fault structures associated with the three major hydrothermal vent areas that were identified included elongate depressions, tilted blocks, and raised ridges that traverse the mid-outer continental shelf within water depths of 175-190 m.

In the north, the Calypso vent area comprises a number of vent sites within $1.5 \mathrm{~km}^{2}$. Dredge samples generally consisted of hydrothermally altered pumiceous ash, sulfur-cemented breccias, and localized massive anhydrite. Vents in the southeast and south-west generally occurred as individual vent outlets occupying small depressions adjacent to faults and clustered within areas of $\sim 500 \mathrm{~m}^{2}$. Specific vents appeared to be localized by collapse features along fault scarps and zones of intense silification that focus fluid flow. Venting fluid temperatures were $180-201^{\circ} \mathrm{C}$.

The silicified sediments occur as large, flat-lying, and locally tilted slabs exposed along the fault scarps and mantled with bacterial filaments, sponges, and anemones. Most recovered samples contain abundant native sulfur and local pyrite. Black, sulfide-stained blocks of pumiceous ash and volcanic breccia were also recovered, many impregnated with light hydrocarbons in fractures and pore spaces. Some $30-40 \%$ of the samples are intensely mineralized, containing abundant pyrite, orpiment, realgar, mercury (cinnabar \pm native mercury), and native sulfur.

A special session at the 1999 AGU Fall Meeting will present results from this and other recent cruises to the KAHB. 

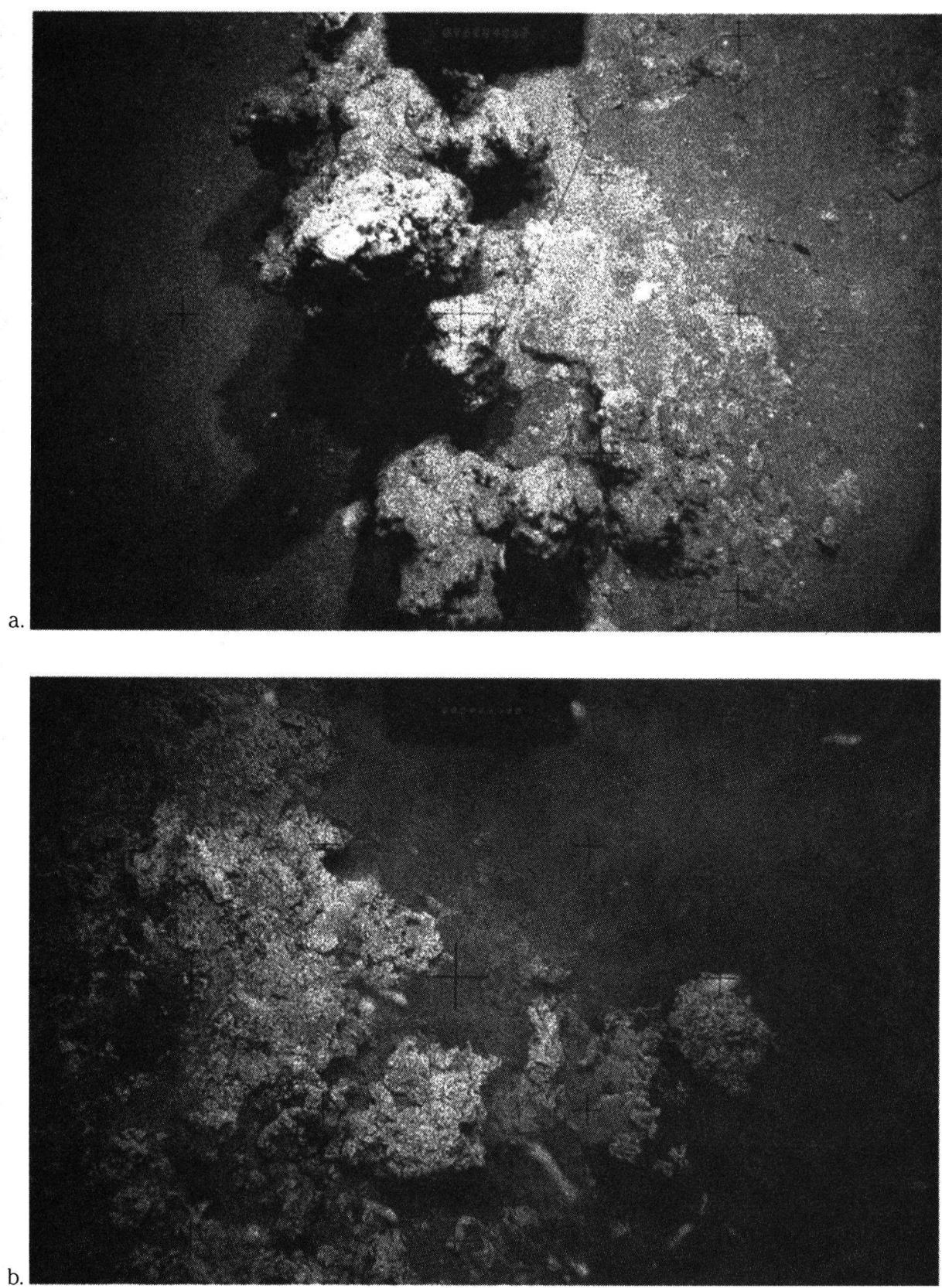

Fig. 2.a) Chimney and associated massive sulfides and talus from the inner north wall of Brothers caldera. Width of view is $\sim 0.9 \mathrm{~m}$. b) Shrimps near vicinity of black smoker vents on lower north wall of Brothers caldera. Width of view is $\sim 1.5 \mathrm{~m}$. Original color image appears at the back of this volume.

\section{Acknowledgments}

Principal funding for this project was provided by the German Federal Ministry for Education, Science, Research, and Technology, Grant No. 03G0135A to PS Additional support was provided by New Zealand's National Institute of Water and Atmospheric Research, the Institute of Geological and Nuclear Sciences, University of Auckland, and the Royal Society of New Zealand, and the Geological Survey of Canada. We thank Master H. Andersen and the officers and crew of the R/V Sonne for their expert technical assistance during the cruise.

\section{Authors}

P. Stoffers, I. C. Wright, C. de Ronde, M. Hannington, H. Villinger, P. Herzig, and the Shipboard Scientific Party

For more information, contact I. C. Wright, National Institute of Water and Atmospheric Research (NIWA), PO Box 14-901, Wellington, New Zealand; E-mail: i.wright@niwa.cri.nz.

\section{References}

Karig, D. E., Ridges and basins of the Tonga-Kermadec Island arc system, J. Geophys. Res., 75, 239-254, 1970.

Pantin, H. M., and I. C. Wright, Submarine hydrothermal activity in the offshore Taupo Volcanic Zone, Bay of Plenty continental shelf, New Zealand, Cont. Shelf Res., 14, 1411-1438, 1994

Sarano, F., R. C. Murphy, B. F. Houghton, and J.W. Hedenquist, Preliminary observations of submarine geothermal activity in the vicinity of White Island volcano, Taupo Volcanic Zone, New Zealand, J.R. Soc. N.Z., 19, 449-459, 1989

Wright, I. C., C. E. J. de Ronde, K. Faure, and J.A. Gamble, Discovery of hydrothermal sulfide mineralisation from southern Kermadec arc volcanoes (SW Pacific), Earth Planet. Sci. Lett., 164, 335-343, 1998

\section{Wegener's Work Included Studies of Noctilucent Clouds,}

\section{Auroras}

\section{PAGES 357,361}

The 120th anniversary of the birth of Alfred Wegener (1880-1930) occurs next year and the event gives us an opportunity to commemorate his work. While the study of continental drift was a significant part of that work,
Wegener's influence is also apparent in other areas of the geosciences, including solar-terrestrial physics, the physics of the upper atmosphere, and meteorology.

Wegener's research in these areas was a continuation of a series of early studies by a number of scientists trying to explain atmospheric phenomena with the known laws of physics. His studies of noctilucent clouds and of auroras, for example, are significant in the context of the history of science as early experiments to explain the terrestrial atmosphere from a profoundly physical point of view. His contributions are building blocks to modern, comprehensive, physical interpretations, just as previous studies were building blocks to his. Wegener followed the same goal, namely the physical explanation of observed and recorded phenomena, and he belonged therefore to that group of researchers who contributed to the early development of geoscience and cos- 
Eos, Vol. 80, No. 32, August 10, 1999

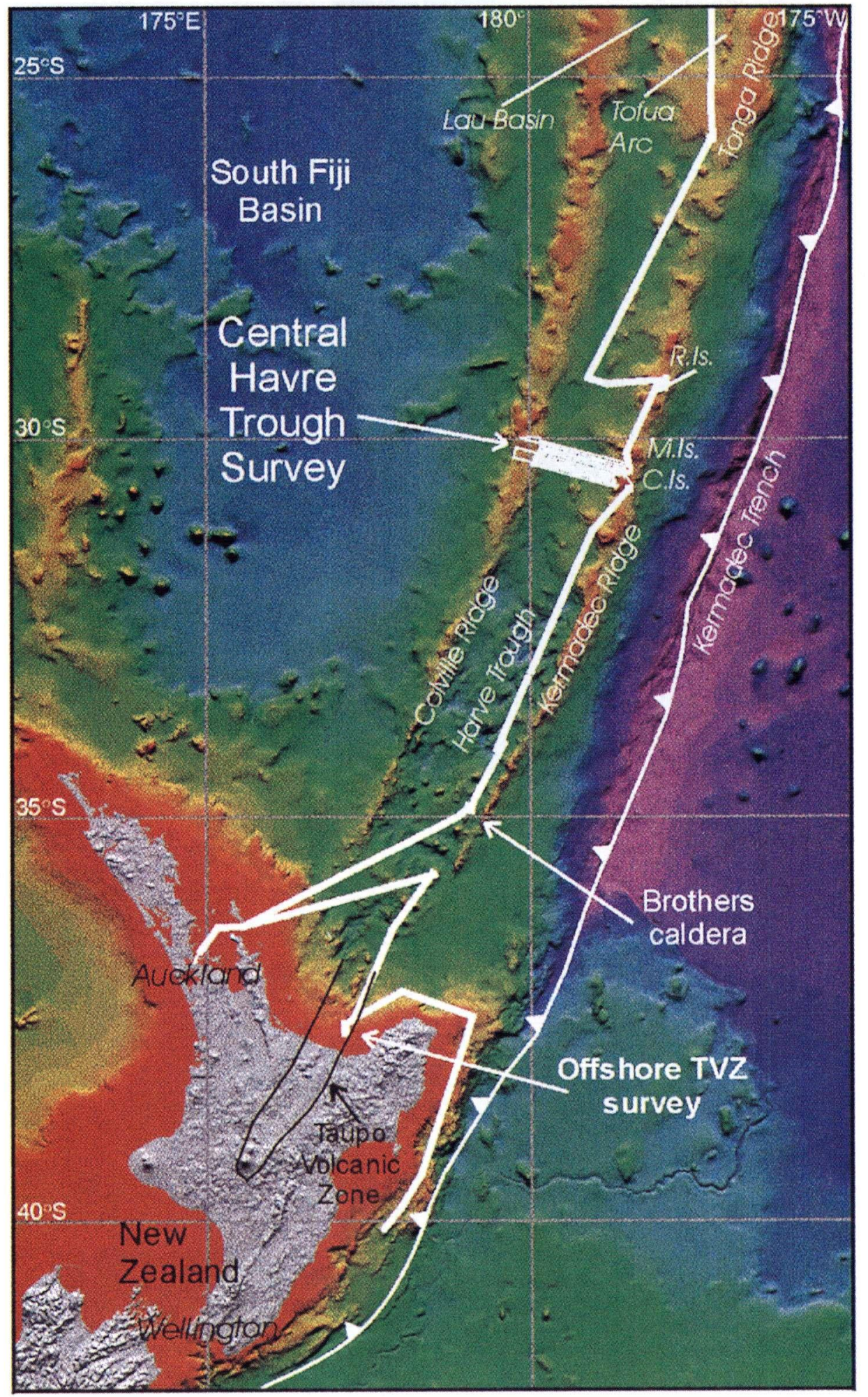

Depths in Metres

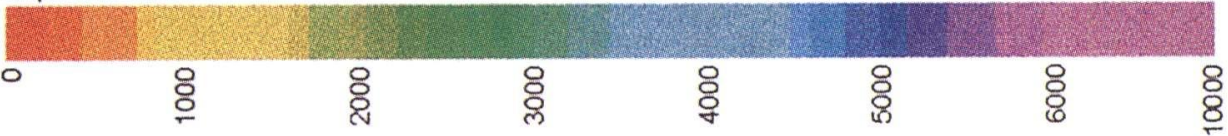

Fig. 1. Regional structure (southwest Pacific) and ship track of the R/V Sonne SO-135 cruise. R.Is., M.Is., and C.Is., are Raoul, Macauley, and Curtis Islands, respectively. 
Eos, Vol. 80, No. 32, August 10, 1999
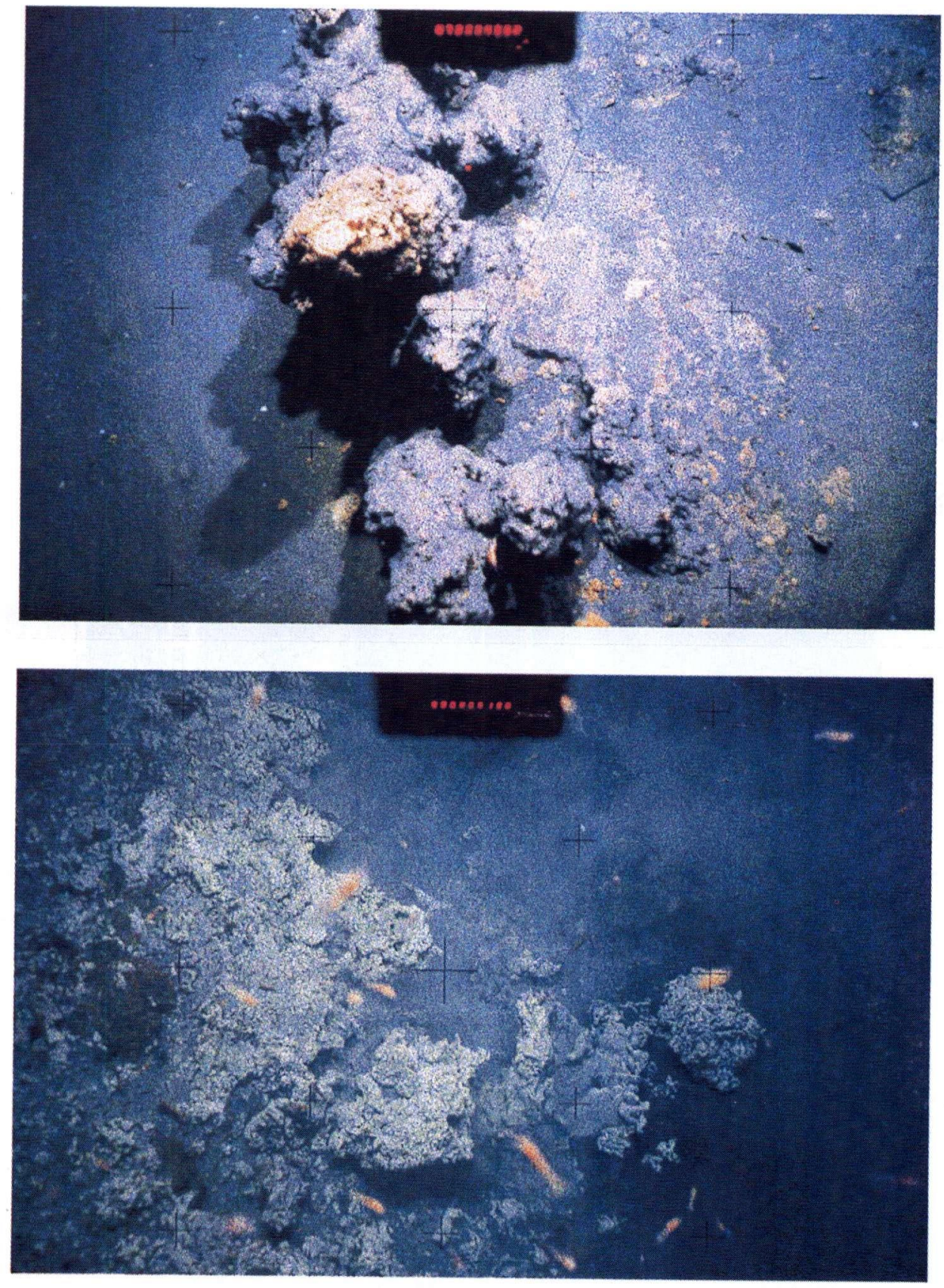

Fig. 2.a) Chimney and associated massive sulfides and talus from the inner north wall of Brothers caldera. Width of view is $\sim 0.9 \mathrm{~m}$. b) Shrimps near vicinity of black smoker vents on lower north wall of Brothers caldera. Width of view is $\sim 1.5 \mathrm{~m}$. 